\title{
TRANSLATING ECONOMICS TEXTBOOKS: A CASE STUDY OF EPISTEMICIDE ${ }^{1}$
}

\author{
Karnedi \\ (karneddie@gmail.com) \\ Universitas Terbuka \\ Jl. Cabe Raya, Pamulang, Tangerang Selatan, 15418, Indonesia
}

\begin{abstract}
As part of discourse in the social sciences, economics textbooks written in English in which knowledge has been transferred to other languages through translation have brought a certain impact on both the target language and the target culture. In terms of ideology, this article argues about the hegemonic status of the dominant language or culture that creates socalled epistemicide or the erosion of knowledge, partly due to translation strategies adopted by the translator. Investigation is done using the corpusbased approach, theories of translation strategies and the comparative model. The study reveals that the translator in the macro-level text adopts the ideology of foreignising strategy rather than domesticating strategy when translating an economics textbook from English into Indonesian. This is supported by the use of the number of the source language-orientated translation techniques leading to two translation methods (i.e. literal translation and faithful translation) adopted in the micro-level text. This research strongly supports another relevant study pertaining to the globalisation of knowledge through translation and also the translation theories of equivalence (i.e. overt and covert translation). The research findings also have some pedagogical implications on teaching English for Specific Purposes in higher education.
\end{abstract}

Keywords: economics text, epistemicide, ideology in translation, knowledge, translation strategies

DOI: http://dx.doi.org/10.15639/teflinjournal.v26i1/59-84

\footnotetext{
${ }^{1}$ An abbreviated version of this paper was presented in Panel 14: Epistemicide Translation and the Globalization of Knowledge at $4^{\text {th }}$ IATIS International Conference at Queen's University Belfast, Northern Ireland, 24-27 July 2012.
} 
Translation as an industry has attracted relevant stakeholders to reproduce science textbooks written in English as the source text (ST) in other target languages (TLs). Local publishers compete with each other in obtaining exclusive publishing and distribution rights to the translated versions of scientific texts from overseas owners to meet the local market demand. As commissioners, the local publishers assign translation jobs to a translator or a team of translators. Usually, they request the translator to do tasks based on personal interest, which could be in economics, commerce or business, politics or social studies, among others. In other words, from the commissioner and/or translator's perspective, ideology often comes into play in the translation. This can be based on the strategies adopted, either overt translation or covert translation (House, 1997).

As far as translating economics discourse is concerned (Backhouse, 1994; Brown, 1994), the transfer of knowledge embodied in economics textbooks from the dominant language/culture to the less dominant language/culture often creates a 'war on knowledge' or the erosion of knowledge in the sense that the hegemonic status of the dominant language/culture might, to some extent, impede the discourse conventions practised in the target language/culture (Bennet, 2007). To put it simply, the so-called epistemicide takes the form of globalisation of knowledge coming from the dominant language/culture through translation. Such translation phenomena do occur in the case of English-Indonesian translation based on a parallel corpus that consists of the ST subcorpus taken from English economics textbooks and the target text (TT) subcorpus (i.e. the Indonesian translated text).

Translation is partly regarded as a product (Hatim \& Mason, 1990). As a product, translation or the translated text can be investigated as an output of the translation process involving the source language (SL) and TL (Catford, 1965). Thus, the role of the translator in this respect is crucial. In performing his task, the translator often encounters various problems and difficulties in translating economics discourse. However, all he needs are several strategies for tackling such problems (Lörscher, 1991; Chesterman, 1997).

As for the epistemicide, this paper examines translation phenomena in association with the ideology in translation at the macro-level text along with the translation methods and translation techniques in the micro-level text; all are considered as part of translation strategies. This is a case study that is based on the experience of the Third World, or Developing Countries (DCs), represented by Indonesia in this respect. In short, discussion in this paper will be focused 
much on how epistemicide does actually take place within the context of English-Indonesian translation using scientific textbooks, especially economics textbooks. ${ }^{2}$

Translating science textbooks, including economics textbooks, from English into other languages and vice versa, to some degree, has an impact on epistemology both in the SL and the TL. Research in Translation Studies conducted so far has some empirical evidence on this phenomenon (Bennett, 2007; Cronin, 2010; House, 2006; Munday, 2009). The effort to globalise knowledge that derives from the dominant epistemology/culture/language has been internationally made through translation activities. The two binary ideologies in translation (i.e. foreignisation and domestication), as put forward by Venuti (1995), are commonly involved and of course relevant in this respect. To begin with, House $(2002,2006)$ once addressed the notion of 'cultural filter' or localisation in translation practice. The concept was actually meant to accommodate sociocultural differences between two communities in terms of linguistic and cultural aspects. At discourse level, English discourse patterns, for instance, are frequently calqued onto the TL. The same technique is also used by translators when dealing with translation at the lower level of translation units such as clauses and phrases, not to mention at the word level. In other words, House's localisation-orientated concept is actually more domestication-based since it considers the TL culture whereas Venuti (1993) labelled this phenomenon as 'domestication regimes', which is regarded as a counter argument.

Bennett $(2007,2008)$, within the context of Portuguese-English translation, also conducted relevant research on the translation phenomenon involving traditional Portuguese academic discourse in the humanities as the data in which two different ideologies/worldviews came together leading to their political and social impact both on the source and the target readers/culture. She found that the notion epistemicide (i.e. 'war on knowledge') in texts translated in English from Portuguese did take place. The same translation phenomenon also takes place within the context of English-Portuguese translation in which calque as a translation technique has been adopted by the translator when rendering English hard sciences into Portuguese. This mainly applies to texts at

\footnotetext{
${ }^{2}$ This paper also aims to explore some advantages of the corpus-based approach in teaching English for Specific Purposes (ESP) that can also be applied when developing other subject-matter-related ESP learning materials such as English for Business, English for Law, etc.
} 
discourse level as ideology as part of translation strategy normally operates at this level of text.

Munday (2009), on the other hand, focused more on how ideology plays a role in the English translation of Latin American writing. By adopting an interdisciplinary approach, he investigated the style of different translators from the literary, cultural and ideological perspectives. The style or voice of translators in the translated text (i.e. stylistic analysis) is based on linguistic choices/patterns made by the translators in accordance with their cultural and ideological framework.

Cronin (2010) seemed to give more emphasis on how TL-orientated within the context of other languages translated into English could lead to language change and have unfavourable influence on the SL discourse conventions. TT, according to Cronin, becomes the so-called "mirror-images of the dominant language" (p. 251) accordingly. In brief, epistemicide is basically a 'declaration of war on knowledge', and could then erode the existing knowledge in the target culture.

Translation theories play a crucial role in translation activities. Translators frequently encounter linguistic-pragmatics-cultural-related problems during the process of translating a given text from the SL into the TL (Ivir, 1987; Katan, 2004). In brief, they need a theory (i.e. translation theory) that they can turn to so that their problems can be solved immediately. Hence, translation strategies are required to successfully render the economics text from the SL into the TL, as suggested by Venuti (1993).

This research study attempts to synthesise a couple of translation strategies as suggested by a number of translation theorists (Larson, 1984; Lörscher, 1991, 2005; Newmark, 1981; Toury, 1995). The definition of translation strategy adopted in this research is as posited by Lörscher (2005), namely "translation strategies are procedures for solving translation problems. They range from the realization of translational problems to its solution or the realization of its insolutibility by a subject at a given moment" (p. 600). The application of translation strategy starts from identifying translation problems by the translator, who then decides the best solution for the problems (Lörscher, 1991). As a result, it is possible for the translator to use various existing translation strategies based on the purpose (skopos) of the translation, as put forward by (Vermeer, 1989), namely "[the skopos rules] can expand the possibilities of translation, increase the range of possible translation strategies, and release the translator from the corset of an enforced - and hence often 
meaningless - literalness" (p. 186). In other words, translation strategies make translation tasks easier for the translator to complete.

The term 'translation technique' is specifically used to translate those lexical items, a combination of words or phrases, clauses and sentences in the ST into the TL. The classification of translation techniques used in this research refers to the category suggested by Molina and Albir (2002), namely adaptation, amplification, borrowing: pure borrowing \& naturalised borrowing, calque, compensation, description, discursive creation, established equivalent, generalisation, linguistic amplification, linguistic compression, modulation, particularisation, reduction, substitution - linguistic, paralinguistic, transposition, and variation.

Translation methods are basically principles on which translators base the process of translating the ST into the TL. Audience design and purpose analysis are the two important factors that would determine the types or forms of translation (Hatim \& Mason, 1997; Hoed, 2006). Below is Newmark's VDiagram (Newmark, 1988), which shows eight translation methods that can be adopted by a translator.

\section{SL Emphasis}

Word-for-word translation

Literal translation

Faithful translation

Semantic translation
TL Emphasis

Adaptation

Free translation

Idiomatic translation

Communicative translation

As seen in the diagram, in order to address the concept of audience design and target readers' needs, the translator may put more emphasis on one of the two different points, either on the SL or on the TL. Newmark's translation methods are, therefore, relevant to this research as they are part of translation strategies (apart from ideology of translation, translation procedures and translation techniques) applied by the translator in dealing with translation problems of economics texts.

The term ideology in this research refers to the definition given by Hatim and Mason (1997), namely "a body of assumptions, which reflects the belief and interest of an individual, a group of individuals, a social institution, etc. and which ultimately find expression in language" (p. 218) and also by Tymoczko (2003), namely "the ideology of a translation resides not simply in the text translated, but in the voicing and stance of the translator, and in its rel- 
evance to the receiving audience" (p. 183). As far as Translation Studies is concerned, according to Penrod (1993), there are two translation strategies commonly adopted by translators: (1) domesticating strategies of translation/domestication focusing on the source language and source culture; (2) foreignising strategies of translation/foreignisation, which is targetlanguage and target-culture orientated.

In addition, Hoed (2003) also stressed the ways in which we should treat the two ideologies (i.e. domestication and foreignisation), particularly within the context of English-Indonesian translation, being open to the two ideologies since they do not only have to do with the target readers' needs but also have their own impact on the target readers, either positive or negative. Moreover, Bennet (2007) pointed out that epistemicide normally operates on various forms. In terms of epistemicide, knowledge with all its conventions coming from different ideological backgrounds (i.e. the dominant one with hegemonic power versus the less dominant ones) has so far been 'at war'. Even though the less dominant culture has been trying to put a lot of effort into balancing the hegemonic status, the dominant culture is always the winner in 'the epistemological battle'.

One of the reasons why English economics textbooks as part of ESP related to subject matter (Flowerdew, 1990; Johns \& Dudley-Evans, 1991; Roberts, 2012) and their Indonesian translations are compiled as the corpus (i.e. the ST and the TT subcorpus) in this study has to do with the fact that university lecturers at faculties of Economics and Business across Indonesia, in particular, those who teach economics, tend to recommend that their students read economics textbooks imported from overseas, apart from other economics textbooks written in Indonesian. In fact, some of those books have been translated into Indonesian by translators hired by local publishers due to market forces even though there have been considerable debate over the quality of the Indonesian-translated books through which the knowledge on economics from English as the dominant language has been transferred into the Indonesian language and culture. In other words, the translation in practice involving the economics textbooks coming from the dominant language and culture (i.e. English) has a great influence on the way in which the existing Indonesian-specific economic concepts like ekonomi kerakyatan (people's economy) are understood and perceived by university students of economics as they have so far been exposed to at least two sources of knowledge on economics written both in English and Indonesian. 
Additionally, much research in Translation Studies reveals that technical texts like economics texts often use specialised terminology both at the word level (e.g. poverty, inflation, growth, price) and also at the phrasal level (i.e. above word level), which linguistically reflects the register of economics texts (Halliday \& Hasan, 1976). The use of such technical terms in a specific text plays a crucial role that makes it different from other kinds of specific texts such as Biology, Aviation and Computer Science texts. Statistically, around $10 \%$ of a specific text like the economics text is technical-orientated, which tends to have higher keyness indexes as suggested by the corpus-based approach. This approach within the ESP areas can be applied to teaching specialised terminology and language patterns used in a specific context, particularly at the higher level of education (Roberts, 2012).

As far as teaching English to students of economics is concerned, developing learning materials is regarded as one of the essential components of curriculum development (Harsono, 2007). Such materials, particularly technical terms in economics texts, need to be selected for teaching purposes on the basis on their frequency of occurrence in a given economics text or corpus.

\section{METHOD}

To achieve the objectives of the study, the methodology consisting of three components (i.e. method, data and data processing) was applied. As for the first component, a qualitative method that took the form of textual analysis was adopted (Travers, 2001; William \& Chesterman, 2002). In addition, a theoretical model of translation, referred to as the comparative model, was also used. The model concerned has the following formula: ST $\approx \mathrm{TT}$ or TT $\approx \mathrm{ST}$ (Williams \& Chesterman, 2002). It was assumed that the ST was more or less the same as the TT and vice versa. According to the model, the process or behaviour of the translation is regarded as a product. In practice, units of translation in the TL are identified before parallelising them with the SL forms. In other words, examples of key words in the economics text as a representation of language in use are compared with their equivalents in the TT. The theory of equivalence is relevant in this respect in that it is widely used to explain the features and relationship between the ST and TT or other smaller units of languages (Baker, 1992; Shuttleworth \& Cowie, 1997). 
The previous method was also supported by a quantitative method, especially frequency of occurrence of some keywords used in the ST subcorpus (Scott, 2008), including the translation techniques adopted by the translator.

The second component of the methodology concerned was a parallel corpus (i.e. the ST subcorpus and the TT subcorpus), which was designed on the basis of representativeness, size, sampling and text types and functions (Baker, 1995, 1996; Bowker \& Pearson, 2002; Olohan, 2004; Zanettin, 2000). The ST subcorpus having around 356,000 tokens was taken from an economics textbook entitled Principles of Economics, $3^{\text {rd }}$ edition (Mankiw, 2003). It was translated into Indonesian by Sungkono (2006) and published locally with the two new titles, Pengantar Ekonomi Mikro, Edisi 3 and Pengantar Ekonomi Makro, Edisi 3 [An Introduction to Microeconomics, $3^{\text {rd }}$ Edition] and [An Introduction to Macroeconomics, $3^{\text {rd }}$ Edition] having 293,000 tokens approximately.

The electronic data (i.e. the parallel corpus) was processed using a concordance programme, called WordSmith Tools version 5.0 (Scott, 2001, 2008). It is used for extracting samples of keywords in context in the ST (the study corpus) and their equivalents in the TT. The British National Corpus (BNC) is also employed as a referent corpus in order to obtain a list of keywords in the ST subcorpus. Shuttleworth \& Cowie (1997) argue over the use of parallel corpora, namely "[...] they provide information not on the native patterns of a target language, but on those of specific target texts, and so give insight into the particular translation practices and procedures which have been used by the translator" (p. 120).

As regards comparative analyses involving the ST and the TT, this research limited its translation units to the sentence-level as the context for some keywords widely used in the ST subcorpus.

\section{FINDINGS AND DISCUSSION}

\section{Keywords in Economics Textbooks}

Having run the WordSmith Tools version 5 involving the economics texts as the study corpus and BNC as the referent corpus, around 500 keywords were extracted by using the computer software; some of which are presented in Ta- 
ble 1 (Scott, 2008, 2011; Karnedi, 2011a, 2011b). Keyness indexes in the right column indicate the importance of those keywords in the economics textbook.

Table 1. Examples of Economics Keywords and Keyness

\begin{tabular}{llcclcc}
\hline $\mathbf{N}$ & \multicolumn{1}{c}{ Keyword } & Freq. & \multicolumn{1}{c}{$\%$} & $\begin{array}{c}\text { RC. } \\
\text { Freq. }\end{array}$ & RC. $\%$ & Keyness \\
\hline 1 & PRICE & 3041 & 0.29851 & 1096 & 0.021992916 & 6417.473633 \\
2 & DEVELOPMENT & 2658 & 0.26092 & 969 & 0.019444466 & 5583.378906 \\
3 & GROWTH & 2198 & 0.21576 & 509 & 0.010213863 & 5372.667969 \\
4 & INCOME & 2260 & 0.22185 & 643 & 0.012902778 & 5189.268066 \\
5 & LABOUR & 1396 & 0.13704 & 6 & & 4878.215332 \\
6 & DEMAND & 2067 & 0.2029 & 592 & 0.011879385 & 4735.506348 \\
7 & SUPPLY & 1770 & 0.17375 & 367 & & 4457.139648 \\
8 & MANAGER & 1416 & 0.139 & 311 & & 3511.325928 \\
9 & GOODS & 1368 & 0.13429 & 263 & & 3510.791748 \\
10 & ECONOMY & 1516 & 0.14881 & 553 & 0.01109679 & 3182.547607 \\
11 & MARKET & 2247 & 0.22057 & 2052 & 0.041176517 & 2785.672852 \\
12 & EMPLOYEE & 1113 & 0.10926 & 252 & & 2736.822754 \\
13 & COST & 1631 & 0.1601 & 1029 & 0.020648457 & 2619.715576 \\
14 & POPULATION & 1242 & 0.12192 & 457 & & 2598.172607 \\
15 & CAPITAL & 1318 & 0.12938 & 560 & 0.011237256 & 2596.024658 \\
16 & TAX & 1411 & 0.13851 & 923 & 0.018521406 & 2216.775391 \\
17 & EQUILIBRIUM & 652 & 0.064 & 15 & & 2175.161133 \\
18 & POVERTY & 767 & 0.07529 & 144 & & 1979.457031 \\
19 & TRADE & 1419 & 0.13929 & 1113 & 0.022334047 & 1975.567505 \\
\hline
\end{tabular}

As seen in Table 1, the keyword PRICE has the highest keyness index (i.e. 6417.473633) in the study corpus, followed by other keywords, such as DEVELOPMENT (i.e. 5583.378906) in the second place and GROWTH (i.e. 5372.667969) in the third place. In other words, the higher the keyness value, and the more statistically significant the different of the keyword across the two corpora (i.e. study corpus and the referent corpus) is. ESP practitioners and teachers should therefore give top priority to these keywords as they are regarded as an indicator of the keywords' importance in a text as content descriptor (Biber et al., 2007; Scott, 2011). 


\section{Translation Strategies}

As far as the translation theories are concerned, translation strategies consist of translation techniques, translation methods, and ideology in translation adopted by the translator (Larson, 1984; Lörscher, 1991, 2005; Newmark, 1981; Toury, 1995; Venuti, 1993; Vermeer, 1989). To identify such strategies, a number of detailed comparative analyses involving the ST and the TT, both at macro- and micro level of the text, were conducted (Nord, 1991; Hatim, 1997; Schäffner, 2003; Bennet, 2007). To begin with, let us look at the following comparative analysis involving the ST (1a) and its Indonesian TT (1b), including its Back Translation (BT).

\section{ST (1a)}

Price equals marginal cost under perfect competition, but price is above marginal cost under monopolistic competition. (Mankiw, 2003)

\section{TT (1b)}

Dalam pasar kompetitif, harga sama dengan biaya marginal. Dalam pasar termonopoli, harga melebihi biaya marginal. (Sungkono, 2006)

\section{BT}

In competitive markets, prices are the same as marginal costs. In monopolistic markets, prices are above marginal costs.

When rendering the ST (1a) into Indonesian (TT, 1b), the translator applies at least three translation techniques (Karnedi, 2011a). The first technique is literal translation whose application can be seen in the following equivalents: price :: harga (literally: price) and marginal cost :: biaya marginal (literally: marginal cost); both the words PRICE and COST are the key words in the ST. Such a translation phenomenon indicates that the translator wishes to maintain the semantic components of the ST (1a) in the TT (1b). Moreover, calque is the second technique employed by the translator as can also be seen in the following equivalent: monopolistic competition :: persaingan monopolistik/pasar termonopoli (literally: monopolistic market). In addition, the translator also applies the naturalised borrowing technique as seen in the following equivalents: marginal :: marginal, competition :: kompetitif and monopolistic :: termonopo$l i$. Based on the last two translation techniques used, it is obvious that the trans- 
lator applies the faithful translation as a translation method which is basically SL-orientated (Fawcett \& Munday, 2009; Hoed, 2003; Munday, 2007). This translation phenomenon reveal that translating economics texts from English into Indonesian does involve the notion of epistemicide (i.e. erosion of knowledge), particularly at the vocabulary and terminology levels; this means that the hegemony of the SL epistemology has been imposed on the TT.

Unlike the previous translation techniques, the following translation technique (i.e. transposition) gives more emphasis to the TL grammatical rules in the TT as indicated by the shift or changes of the ST forms in the TT as seen in the TT (1b). This is done by changing the complex sentence in the ST (1a) into two simple sentences in TT (1b). The translation is no longer restricted by the sentence construction or patterns in the ST. In other words, the effort is made in order to make the TT not to be read as a translation (i.e. readership).

Deleting some lexical items in the ST (1a) also takes place. For instance, the word perfect as in the phrase under perfect competition is rendered as dalam pasar kompetitif (literally: in competitive market) in Indonesian, including the deletion of the conjunction but which links the two sentences in the ST (1a). The application of such a technique is called 'deletion' or 'omission'. Even though the first deletion does not really impede communication or comprehension in the TT, the second deletion does create problems in the TT since conjunctions as cohesive markers/devices whose function is to show contrast between sentences play an important role not only in the structure of the ST but also in the TT. The last two translation techniques highlighted above have TL orientation.

The following analysis will focus on the translation of the ST (2a) having the same key word (i.e. PRICE) into Indonesian, but it is more likely to be SLorientated based on the translation techniques used.

ST (2a)

But the price of oil (adjusted for overall inflation) has never returned to the peak reached in 1981. (Mankiw, 2003)

$\mathrm{TT}(2 \mathrm{~b})$

Akan tetapi harga minyak (disesuaikan dengan inflasi keseluruhan) tidak pernah kembali ke puncaknya yang pernah dicapai pada tahun 1981. (Sungkono, 2006) 


\section{BT}

However, oil prices (adjusted for the whole inflation) have never returned to their peak reached in 1981.

To overcome the translation problems in dealing with the ST (2a), the translator applies at least three translation techniques: literal translation, naturalised borrowing and transference. In terms of literal translation, several equivalents have been chosen, as follows: price of oil :: harga minyak (literally: oil price), adjusted :: disesuaikan (literally: adjusted), return :: kembali (literally: be back to) and peak :: puncak (literally: top). The use of such techniques is intended to preserve the semantic aspects of the ST (2a) in the TT (2b). In addition to this, the application of naturalised borrowing can also be seen in the translation of the word inflation into inflasi in Indonesian. This again stresses the fact that the translator wishes to maintain the ST features in the TT.

As for the ST syntactical structure, the translator also applies transference as a translation technique as seen in the following equivalent: but the price of oil (adjusted for overall inflation) has never returned to the peak reached in 1981 (ST) :: akan tetapi harga minyak (disesuaikan dengan inflasi keseluruhan) tidak pernah kembali ke puncaknya yang pernah dicapai pada tahun 1981 (TT, 2b), which has faithfully followed the sentence construction of the ST (2a).

Unlike the previous comparative analyses that were based on the key word PRICE, the next translation analysis will give more emphasis on how the ST (3a) has been rendered into Indonesian as seen in the TT (3b) in which the key word DEMAND is used in context.

ST (3a)

The demand curve for money is downward sloping, indicating that when the value of money is low (and the price level is high), people demand a larger quantity of it to buy goods and services. (Mankiw, 2003)

\section{TT (3b)}

Kurva permintaan uang berbentuk curam ke bawah, menandakan bahwa ketika nilai uang rendah (dan tingkat harga tinggi), masyarakat meminta jumlah uang yang lebih besar untuk membeli barang dan jasa. (Sungkono, 2006) 
BT

The demand curve for money is downward sloping, showing that when the value of money is low (and the level of price is high), people demand a larger amount of money to buy goods and services.

The ST (3a) has been translated into Indonesian using at least four translation techniques: literal translation, naturalised borrowing, descriptive and explicitation (Karnedi, 2011a); the first two techniques are clearly SL-orientated whereas the last two techniques have, in fact, the TL orientation. In case point of the literal translation, the following equivalents provide some evidence for this: value of money :: nilai uang (literally: the value of money), price level :: tingkat harga (literally: the level of price), to demand :: meminta (literally: to demand), to buy :: membeli (literally: to buy), and goods and services :: barang dan jasa (literally: goods and services). The use of such technical terminology in the ST (3a) and their equivalents in the TT (3b) reflects how semantic components of the ST (3a) are strongly preserved in the TT (3b) on the basis of the TL rules.

Naturalised borrowing is another translation technique applied by the translator. For example, the word kurva in the phrase kurva permintaan (literally: the curve for demand) as the equivalent for demand curve has gone through both spelling and pronunciation adjustment in the TL. Additionally, the application of transference can also be seen in the TT (3b) since it follows the ST construction, even in the use of punctuation such as comma and brackets. In other words, the translator is faithful to the intention of the ST writer by structurally following the construction of the ST in the TT produced (Molina \& Albir, 2002; Vinay \& Darbelnet, 1958/1995).

Unlike the last three translation techniques which are in favour of the SL, the next two translation techniques (i.e. descriptive and explicitation) have been adopted in order to solve the translation problems. By selecting the alternative equivalent berbentuk curam ke bawah (literally: take the form of downsloping) in the TT (3b), the translator tries to describe the phrase downward sloping using a few words in Indonesian. Additionally, apart from the descriptive technique, the translator also tries to express the pronoun it in the phrase a larger quantity of it more transparent in the TT (3b) by adding the word uang (literally: money) as in jumlah uang yang lebih besar (literally: a larger amount of money), which makes the pronoun more explicit in the TT (3b). In this in- 
stance, something implicit in the ST has been made more explicit in the TT (Baker \& Olohan, 2000; Blum-Kulka, 1986; Séguinot, 1988; Vanderauwera, 1985; Vinay \& Darbelnet, 1958). From the perspective of translation strategies, this is an effort made by the translator in order to be as close as possible to the TL. Hence, this can also increase the level of readership of the TT. However, from the SL point of view, the BT clearly reveals that the use of the word money twice in the translated text (TT, $3 \mathrm{~b}$ ) is regarded as something that is redundant and should therefore be avoided. In brief, epistemicide could actually occur in both directions of translation, either from the SL to the TL or vice versa. The previous translation phenomenon adopts the domesticating strategy of translation as it is TL-orientated, while the latter adopts the foreignising strategy of translation as it is SL-based.

\section{Translation Techniques and Translation Methods}

As far as translation techniques operating at the micro-text level are concerned, this research revealed that there were 11 techniques used by the translators in translating Economics texts (ST-subcorpus) into Indonesian (Baker, 1992; Hoed, 2006; Molina \& Albir, 2002; Newmark, 1988; Vinay \& Darbelnet, 1958/1995), as seen in Figure 1. The first two techniques (i.e. literal translation with $28.63 \%$ frequency of occurrence and naturalised borrowing with $22.47 \%$ frequency of occurrence) together with transference with $7.05 \%$ frequency of occurrence), calque with $6.61 \%$ frequency of occurrence, and pure borrowing with $1.76 \%$ frequency of occurrence reflect the fact that the translator prefers to maintain semantic aspects, including the grammatical structure/syntax, of the $\mathrm{ST}$ in the TT. Therefore, they are more SL-orientated in nature, having roughly $66.52 \%$ frequency of occurrence in total; this figure outweighs the figure for those translation techniques having the TL orientation (i.e. transposition, modulation, deletion, explicitation, addition and descriptive), with only $33.48 \%$ frequency of occurrence. This translation phenomenon is congruous with the notion of overt translation and covert translation, as pointed out by House (1997).

This tendency again supported the previous conclusions that the translator was in favour of both literal and faithful translation methods, including perhaps semantic translation, as the main principle in translating the ST into the TL (Hoed, 2006; Newmark, 1988), as also found in other relevant research projects (Izwaini, 2004; Silalahi, 2009). Moreover, this translation phenomenon was also closely linked to the concept of "cultural filter", as suggested by House 
(2006, p. 349). Knowledge in this instance was dominated by the dominant culture/language, which is English. In other words, the so-called evaluation of epistemicide or hegemony was valid in the sense that knowledge coming from the dominant culture was globalised through translation using the ideology of foreignisation in which translation in the target culture/language was simply providing mirror-images of English, the dominant language.

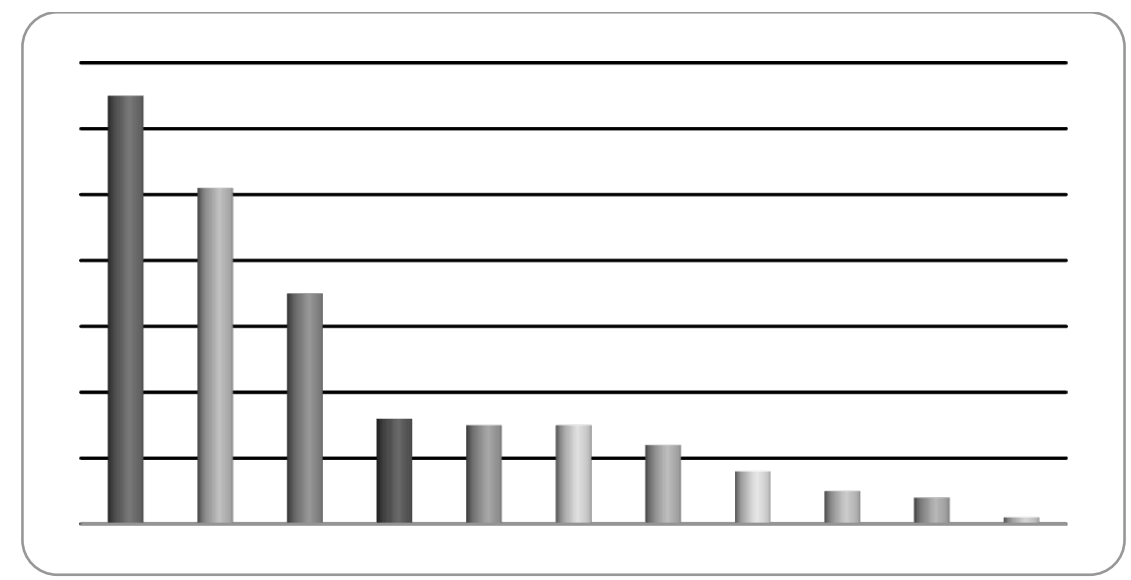

$\mathrm{n}=227$

Figure 1. Translation Techniques Adopted

\section{Ideology in Translation}

As mentioned earlier, the application of the SL-orientated techniques for translating economics texts reached $66.52 \%$ whereas the figure for the TLbased translation techniques was $33.48 \%$. In terms of ideology in translation, on the basis of the two figures, it can be concluded that the translator adopted the foreignising strategy of translation (foreignisation) rather than domestication when rendering the economics text from English into Indonesian (Munday, 2008; Venuti, 1995). This finding is seen in Figure 2, which shows a continuum that covers the three major components of translation strategies adapted from some of the translation scholars mentioned earlier (Karnedi, 2011a, 2011b). 


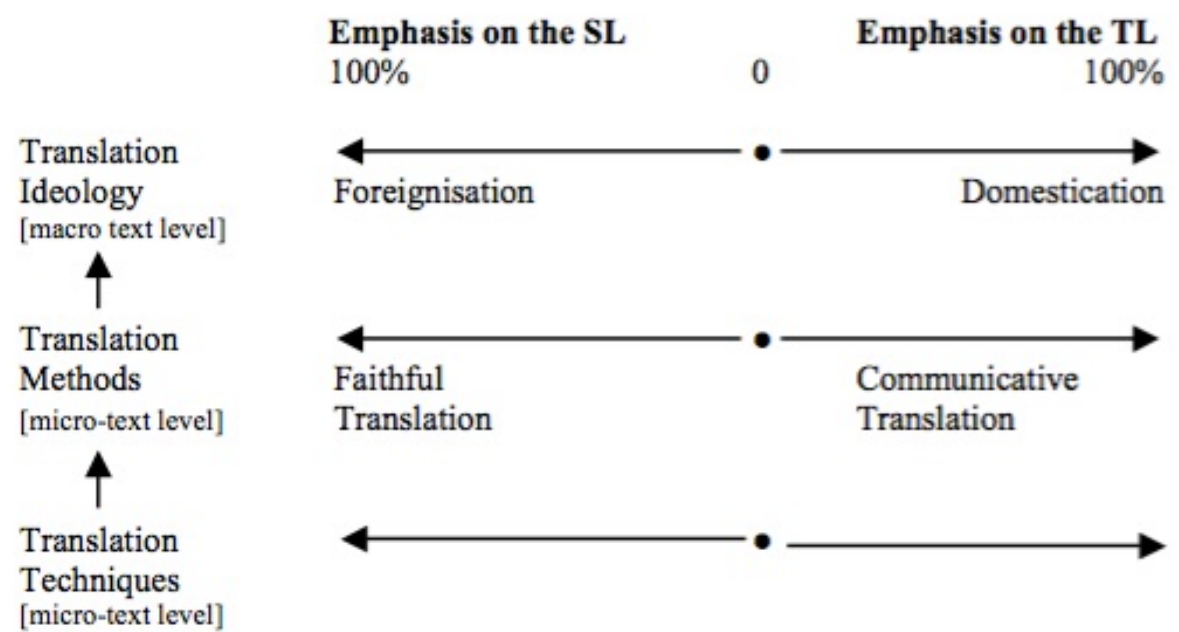

Figure 2. The Relationship among Components of Translation Strategies

\section{Some Pedagogical Implications}

The research findings highlighted in the previous section also have some pedagogical implication, especially within the context of teaching ESP (Dudley-Evans, 1998; Strevens, 1988). As part of ESP, English for economics texts, or economics-related teaching and learning materials are specially designed to meet specific needs of adult learners (e.g. university students of economics). The learners need to have the language skills in order to understand those economics concepts and realities explained in economics textbooks and use them in daily communication activities.

As far as the methodology is concerned, teaching English for university students of economics as part of ESP areas (Roberts, 2012) can also use the corpus-based approach adopted in this research (Römer, 2010). As mentioned earlier, the parallel corpus for this research consisted of two subcorpora designed on the basis of some criteria ${ }^{3}$ - the source text subcorpus coming from an English economics text and its Indonesian translation as the target subcorpus. In preparing the teaching materials for the students of economics, with a

\footnotetext{
${ }^{3}$ Such as corpus representativeness, corpus size, corpus balance, sampling, text types
} 
corpus in hand or from the Internet, the concordance programme (e.g. Wordsmith Tools 5.0) can be utilised to elicit keywords and language patterns (collocation) in the ST subcorpus as seen in Table 2.

\section{Table 2. Some Concordance Lines for the Keyword PRICE}

EC found it difficult to maintain a high price. From 1982 to 1985, the surprising that monopolies charge high prices for their products. of oil outside of OPEC respond to high prices by increasing oil and sell a large quantity at that high price. The market demand curve level of profit they want, because high prices reduce the amount that monopolist could command quite a high price, even if the marginal cost from buying health insurance by the high price. adverse selection the of the owners of the firm, the high price makes monopoly very is connected to the monopoly's high price: Consumers'buy fewer.units , STRONG Demand leads to high prices and high profits, which drug addicts are willing to pay a high price for heroin. Yet we would and whether Big Brew sets $a$ high price or a low price: Big Brew after the insurance is bought. The high price of insurance is why some and for beef. Explain in words. 8. "High prices traditionally cause , eventually bringing an end to high prices and manufacturers' has a high marginal product and a high price. As a result, when the problems are discouraged by the high price from buying health would happen, but when you outlaw high prices you create real problems. only John is willing to pay such $a$ high price. If the price is between defender of the poor by declaring high prices illegal," says William J. is inelastic. At points with $a$ high price and low quantity, the

either a high price for tickets or $a$ low price. If one company charges Sticky-Wage Theory: An unexpectedly low price level raises the real wage, Sticky-Price Theory: An unexpectedly low price level leaves some firms money. Instead of charging such $a$ low price, the monopoly firm would are cheap, which she measures by a low price-earnings ratio. How do you midpoint method. At points with a low price and high quantity, the from being able to buy heroin at a low price (even though addicts might axis on the right is inverted: $A$ low price level is shown near the top consumers would benefit from the low price. Moreover, the case for them rather than sell them at the low price that skeptical buyers are money. Instead of charging such a low price, the monopoly firm would

Sticky-Wage Theory.- An unexpectedly low price level raises the real wage, also give the "high" and "low" prices over the past day of 
perceptions Theory: An unexpectedly low price level leads some suppliers Big Brew sets a high price or $a$ low price: Big Brew High Price Low consumers would benefit from the low price. Moreover, the case for

As seen in Table 2, the word price (as a node) collocates with certain adjectives (apart from certain nouns) such as high, low, reasonable, attractive, fair, actual, annual, average, constant, current, different, domestic, effective, good, international, new, relative, rental, same, sharp, single, total, various. On the other hand, in an Indonesian monolingual corpus, as seen in Table 3, the word harga (price) generally collocates with the adjectives murah (literally: cheap) and mahal (literally: expensive) as in harga murah (literally: cheap price) and harga mahal (literally: expensive price), including harga rendah and harga tinggi (literally: low and high price). However, the first two examples (i.e. harga murah and harga mahal) are specifically bound to Indonesian culture.

In addition to this, teachers or ESP practitioners can also design much more challenging learning activities that are learner-centred (Hutchinson \& Waters, 1987) by giving students translation tasks at the sentence level where phrases such as harga rendah and harga mahal, for instance, may be used as in the Indonesian economics text used in this analysis, as seen in Table 3. If the students adopt literal translation as a translation technique, which is SLorientated, they might come up with English translations like cheap price and expensive price, which are unacceptable in English as they violate the rules of English collocational patterns (i.e. low and high price). In other words, based on wider knowledge of these different grammatical rules, specialised terminology and also with continuous language practice, students of economics, in particular, should be able to communicate successfully across languages and cultures.

Table 3. Concordance Lines for the Keyword HARGA

mengapa Bimantara mau menjual dengan harga murah? Ternyata ini juga tetangga. "Daripada mengobralnya dengan harga murah, menjatuhkan menginginkan kenyamanan selain harga murah, Jackson juga ber BBM lebih banyak orang kaya. Akibat harga murah itu, kita terlena dan toko milik kerabatnya. Tentu saja dengan harga lebih tinggi. "Ya, kalau di dikonsumsi ke negara berkembang dengan harga lebih murah dari dalam menjual produk ke negara lain dengan harga lebih rendah dari perkiraan 
Airlines misalnya, mampu menawarkan harga tiket lebih murah dengan bisa memperoleh bahan sembako dengan harga yang relatif murah," kata sekarang, mereka juga bisa mendapatkan harga yang relatif lebih murah.

\section{CONCLUSIONS AND SUGGESTIONS}

As the world economy keeps changing rapidly, translation has turned into a promising industry. Stakeholders in this sector play a very important role in producing translation versions involving many other languages worldwide. Translating science textbooks like economics textbooks from English as the SL into Indonesian as the TL has also become part of this cross-cultural activity (Katan, 2004). However, the erosion of knowledge embodied in the given texts has been unavoidable. As the dominant culture from which the knowledge comes, English features and conventions have been adapted to the less dominant culture through translation. In other words, the TT is regarded as "mirrorimages" of the source language and culture (Cronin, 2010, p. 251), and this leads to language change from the view point of the TL. During the process of translation, translating scientific textbooks into Indonesian frequently causes problems (Larson, 1984; Newmark, 1988; Schäffner, 2003). In order to overcome such problems, certain translation strategies are required (Lörscher, 1991, 2005). Translation strategies normally cover several components: translation ideology, translation methods and translation techniques. Translation strategies actually reflect the various efforts made by the translator in dealing with the translation of economics texts from the SL into the TL, starting from the microtext level up to the macro-text level.

This research shows that at the macro-text level, the translator adopted the foreignising strategy of translation (i.e. foreignisation). The translator wished to maintain the meanings and characteristics of the ST in the TT (i.e. overt translation). However, less attention was given to the characteristics of the TL in the TT (i.e. covert translation). The translator's ideological perspective supported the theory of translation, particularly as to how translating ideologies should be treated (Fawcett \& Munday, 2009; Hoed, 2003; House, 2001; Mason, 1992; Van Dijk, 1998; Venuti, 1995).

The ideological preference at the macro-text level could be traced up to the micro-text level by identifying the use of certain translation methods and techniques when there are problems with translating economics texts from the 
SL into Indonesian. This research was also in line with the assumption implied by the V-Diagram (Newmark, 1988), which states that in doing his task, the translator is faced with two options, either favouring the SL or the TL (or perhaps a mixture of the two). The final decision as to which option to choose is for the translator himself to make.

This research also provided some evidence that the major causes of translation problems can be divided into three main categories: (1) linguistics-based - structural and system differences between two languages; 2) pragmaticsbased - outside contextual factors affecting the success of communication through the translation process; and 3) culture-based - conventions practiced in a community (Ivir, 1987). It is, therefore, necessary to apply various strategies for translating economics textbooks from English into Indonesian in order to achieve the aims or skopos of the translation itself (Nord, 1997; Vermeer, 1989). This is because the translator as communicator, together with the TT writer and the target readers, is part of the communication process.

The findings in this research also support a number of alternative translation techniques put forward by translation theorists such as Newmark (1988), Vinay and Darbelnet (1958/1995), and many others although it should be mentioned that there are similarities among the translation techniques suggested.

As for teaching ESP, the research findings also have some pedagogical implications on teaching English for economics partly through translation, some of which relate to the methodology (i.e. corpus-based approach) that can be adopted by ESP practitioners in the design of learning materials based on corpora which contain authentic texts on economics, and a selection of language focus relating to the register of various categories of economics (i.e. technical terms/terminology, and grammar in terms of regular recurrence of language patterns in economics texts). In brief, having the knowledge and language skills will enable students to participate in economics-related discourse communities (i.e. communicative competence).

One of the weaknesses of this research is that it should have operated at discourse level rather than at sentence level, at which ideology resides, including ideology on translation (Munday, 2007; Tymoczko, 2003). Therefore, further research needs to be done involving not only various discourses but also what happens when there are changes to the direction of translation (i.e. Indonesian-English translation) to see whether or not the phenomenon of epistemicide through translation does occur within the context of Indonesian-English translation. 
Karnedi, Translating Economics Textbooks 79

\section{REFERENCES}

Backhouse, R. E. (Ed.). (1994). New directions in economic methodology. London: Routledge.

Baker, M. (1992). In other words: A coursebook on translation. London: Routledge.

Baker, M. (1995). Corpora in translation studies: An overview and some suggestions for future research. Target, 7(2), 223-243.

Baker, M. (1996). Corpus-based translation studies: The challenges that lie ahead. In H. Somers (Ed.). Terminology, LSP and Translation. Studies in language engineering in honour of Juan C. Sager, pp. 175-186. Philadelphia/Amsterdam: John Benjamins.

Bennett, K. (2007). Epistemicide! The tale of a predatory discourse. The Translator, 13(2), 151-169.

Bennett, K. (2008). English academic discourse: Its hegemonic status and implications for translation. Dissertation.Universidade de Lisboa.

Biber, D., Connor, U. \& Upton, A. with Anthony, M. \& Gladkov, K. (2007). Rhetorical appeals in fundraising. In D. Biber, U. Connor \& A. Upton. Discourse on the Move: Using corpus analysis to describe discourse structure (pp.121-151). Amsterdam: John Benjamin.

Bowker, L., \& Pearson, J. (2002). Working with specialized language: A practical guide to using Corpora. London: Routledge.

Brown, V. (1994). The economy as text. In R. E. Backhouse (Ed.). New directions in economic methodology (pp. 368-382). London: Routledge.

Catford, J. C. (1965). A linguistic theory of translation. London: Oxford University Press.

Chesterman, A. (1997). Memes of translation: The spread of ideas in translation theory. Amsterdam/Philadelphia: John Benjamins.

Cronin, M. (2010). Translation and globalization. London: Routledge.

Dudley-Evans, T. (1998). Developments in English for specific purposes: A multi-disciplinary approach. Cambridge: Cambridge University Press. 
Fawcett, P., \& Munday, J. (2009). Ideology. In M. Baker (Ed.). Routledge encyclopedia of translation studies (pp. 137-140). London: Routledge.

Flowerdew, J. (1990). English for specific purposes - a selective review of the literature. ELT Journal, 44(4), 326-337.

Halliday, M. A. K. \& Hasan, R. (1976). Cohesion in English. London: Longman.

Harsono, Y. M. (2007). Developing learning materials for specific purposes. TEFLIN Journal, 18(2), 169-179.

Hatim, B., \& Mason, I. (1990). Discourse and translator. London: Longman.

Hatim, B. (1997). Communication across cultures: Translation theory and contrastive text linguistics. Exeter: University of Exeter Press.

Hatim, B., \& Mason, I. (1997). The translator as communicator. London: Routledge.

Hoed, B. H. (2003). Ideologi dalam penerjemahan. The paper was presented at the National Translation Seminar, Tawangmangu.

Hoed, B. H. (2006). Penerjemahan dan kebudayaan. Jakarta: Pustaka Jaya.

House, J. (1997). Translation quality assessment: A model revisited. Türbingen: Gunter Narr.

House, J. (2001). Translation quality assessment: Linguistic description vs social evaluation. Meta, XLVI(2), 243-257.

House, J. (2002). Communicating in English as a lingua franca. In S. FosterCohen (Ed.). EUROSLA Yearbook 2 (pp. 243-261). Amsterdam: Benjemins.

House, J. (2006). Covert translation, language contact, variation and change. SYNAPS, 19, 25-47.

Hutchinson, T., \& Waters, A. (1987). English for specific purposes: A learnercentered approach. Cambridge: Cambridge University Press.

Ivir, V. (1987). Procedures and strategies for the translation of culture. Indian Journal of Applied Linguistics, 13(2): 35-46. 
Izwaini, S. (2004). Translation and the language of information technology: A corpus-based study of the vocabulary of information technology in English and its translation into Arabic and Swedish. (Doctoral dissertation, University of Manchester (UMIST), Manchester, England).

Johns, A. M., \& Dudley-Evans, T. (1991). English for specific purposes: International in scope, specific in purpose. TESOL Quarterly, 25(2), 297-314.

Karnedi. (2011a). Translating conceptual metaphors: A case study of translating economics textbooks from English into Indonesian. (Doctoral dissertation, University of Indonesia (UI), Jakarta, Indonesia).

Karnedi (2011b). Translating conceptual metaphors: A case study of translating economics textbooks from English into Indonesian. Lintas Bahasa Translingua, 15(1), 63-98.

Katan, D. (2004). Translating cultures: An introduction for translators, interpreters and mediators. Manchester: St. Jerome Publishing.

Larson, M. L. (1984). Meaning-based translation: A guide to cross-language equivalence. London: University Press America, Inc.

Lörscher, W. (1991). Translation performance, translation process, and translation strategies: A psycholinguistic investigation. Turbingen: G. Narr.

Lörscher, W. (2005). The translation process: Models and problems of its investigation. Meta, 50(2), 597-608.

Mankiw, N. G. (2003). Principles of economics (3rd ed). USA: South-Western.

Mason, I. (1992). Discourse, ideology, and translation. In A. de Beaugrande \& M. H. Heliel (Eds.). Language, discourse and translation in the West and Middle East (pp. 23-34). Amsterdam: John Benjamins.

Molina, L. \& Albir, H. A. (2002). Translation technique revisited: A dynamic and functionalist approach. Meta, XLVII(4), 498-512.

Munday, J. (2007). Translation and ideology: A textual approach. The Translator, 13(2), 195-217.

Munday, J. (2008). Style and ideology in translation: Latin American writing in English. London: Routledge. 
Munday, J. (2009). Style and ideology in translation: Latin American writing in English. London: Routledge.

Newmark, P. (1981). Approaches to translation. Oxford: Pergamon.

Newmark, P. (1988). A textbook of translation. Hertforshire: Prentice Hall International (UK) Limited.

Nord, C. (1991). Text analysis in translation: Theory, methods and didactic application of a model for translation-oriented text analysis. Amsterdam: Rodopi.

Nord, C. (1997). Translation as a purposeful activity. Manchester: St. Jerome.

Olohan, M., \& Baker, M. (2000). Reporting that in translated English: Evidence for subconscious processes of explicitation? Across Languages and Cultures, 1(2), 141-158.

Olohan, M. (2004). Introducing corpora in translation studies, London: Routledge.

Penrod, L.K. (1993). Translating Hélène Cixous: French feminism(s) and Anglo-American feminist theory. TTR (Traduction, Terminologie, Redaction), 6(2), 39-54.

Roberts, M. (2012). English for Economics in higher education studies. Reading: Garnet Education.

Römer, U. (2010). Using general and specialized corpora in English language teaching: Past, present and future. In M. C. Campoy, B. Belles-Fortuno, \& M. L. Gea-Valor (Eds). (2010). About corpus-based approaches to English language teaching (pp. 267-287). London: Continuum.

Schäffner, C. (2003). Third ways and new centres: Ideological unity or difference? In M. Calzada-Pérez (Ed.) Apropos of ideology (pp. 23-42). Manchester: St. Jerome.

Scott, M. (2001). Comparing corpora and identifying key words, collocations, frequency distributions through the Wordsmith tools suite of computer programs. In M. Ghadessy, A. Henry \& L. Roseberry (Eds.). Small corpus studies and ELT (47-67). Amsterdam: Benjamins. 
Scott, M. (2008). WordSmith Tools version 5. Liverpool: Lexical Analysis Software.

Scott, M. (2011). WordSmith Tools Manual, Version 6. Liverpool: Lexical Analysis Software Ltd.

Shuttleworth, M., \& Cowie, M. (1997). Dictionary of translation studies. Manchester: St. Jerome Publishing.

Silalahi, R. (2009). Dampak teknik, metode, dan ideologi penerjemahan pada kualitas terjemahan teks medical-surgical nursing dalam bahasa Indonesia [The impact of the translation techniques, methods, and ideologies on the quality of the translated text medical-surgical nursing in bahasa Indonesia]. (Doctoral dissertation, Graduate School of Universitas Sumatera Utara (USU), Medan, Indonesia).

Strevens, P. (1988). ESP after twenty years: A re-appraisal. In M. Tickoo (Ed.). ESP: State of the art (pp. 1-13). Singapore: SEAMEO Regional Language Centre.

Sungkono, C. (2006). Pengantar ekonomi mikro, edisi 3 [An introduction to microeconomics, $3^{\text {rd }}$ edition] and Pengantar ekonomi makro, edisi 3 [An introduction to macroeconomics, $3^{\text {rd }}$ edition]. Jakarta: Salemba Empat.

Toury, G. (1995). Descriptive translation studies - and beyond. Amsterdam/ Philadelphia: John Benjamins.

Travers, M. (2001). Doing qualitative research through case studies. London: Sage.

Tymoczko, M. (2003). Ideology and the position of the translator: In what sense is a translator "in between?" In M. Calzada Perez (Ed.). Apropos of ideology: Translation studies on ideology - Ideologies in translation studies (pp. 181-201). Manchester: St Jerome.

Van Dijk, T. A. (1998). Ideology: A multidisciplinary approach. London: Sage.

Venuti, L. (1993). Translation as cultural politics: Regimes of domestication in English. Textual Practice, 7(2), 208-223.

Venuti, L. (1995). The translator's invisibility. London: Routledge. 
Vermeer, H. (1989). Skopos and commission in translational activity. In L. Venuti (Ed.). The translation studies reader (pp. 221-232). London: Routledge.

Vinay, J. P., \& Darbelnet, J. (1958/1995). Comparative stylistics of French and English: A methodological for translation (translated and edited by Juan C. Sager \& M.-J. Hamel). Amsterdam \& Philadelphia: John Benjamin Publishing Company. [Translation of Vinay \& Darbelnet 1958.]

Williams, J., \& Chesterman, A. (2002). The MAP: A beginner's guide to doing research in translation studies. Manchester: St. Jerome Publishing.

Zanettin, F. (2000). Parallel corpora in translation studies: Issues in corpus design and analysis. In M. Olohan (Ed.). Intercultural faultlines: Research models in translation studies: Textual and cognitive aspects (pp. 105118). Manchester: St Jerome. 